\title{
Ability of nitrapyrin, dicyandiamide and acetylene to retard nitrification in a mineral and an organic soil
}

\author{
K.L. SAHRAWAT ${ }^{1}$, D.R. KEENEY and S.S. ADAMS \\ Department of Soil Science, University of Wisconsin-Madison, Madison, WI 53706, USA \\ ${ }^{1}$ Present address: International Crops Research Institute for the Semi-Arid Tropics (ICRISAT), ICRISAT \\ Patancheru P.O.; A.P. 502324, India
}

Received 14 May 1986. Revised September 1986

Key words: nitrification inhibitors, histosol

\begin{abstract}
Laboratory experiments were conducted to evaluate the efficacy of nitrapyrin, dicyandiamide (DCD) and acetylene $\left(\mathrm{C}_{2} \mathrm{H}_{2}\right)$ as nitrification inhibitors in a silt loam and oragnic soil with and without added $\mathrm{NH}_{4}$. Nitrapyrin $(8 \mu \mathrm{g} / \mathrm{g}$ soil $)$ and DCD $\left(20 \mu \mathrm{g} / \mathrm{g}\right.$ soil) were very effective in retarding nitrification of $\mathrm{NH}_{4}-\mathrm{N}_{\text {in }}$ the silt loam soil during 14 days of aerobic incubation at $30^{\circ} \mathrm{C}$. However neither nitrapyrin $(20 \mu \mathrm{g} / \mathrm{g}$ soil) nor DCD ( 20 or $100 \mu \mathrm{g} / \mathrm{g}$ soil) were effective in retarding $\mathrm{NO}_{3}$ production in the organic soil not amended with $\mathrm{NH}_{4} \cdot$ Dicyandiamide was moderately effective in retarding nitrification ( $39 \%$ inhibition) at $100 \mu \mathrm{g} / \mathrm{g}$ concentration but nitrapyrin at $20 \mu \mathrm{g} / \mathrm{g}$ rate had little effect ( $8 \%$ inhibition) on nitrification in the organic soil amended with $\mathrm{NH}_{4}$. In a separate experiment $\mathrm{C}_{2} \mathrm{H}_{2}$ was a very effective inhibitor in both soils when present in the flask atmosphere at $0.1 \%$ or $1 \%(\mathrm{v} / \mathrm{v})$.
\end{abstract}

\section{Introduction}

The efficacy of synthetic organochlorine nitrification inhibitors such as nitrapyrin [2-chloro-6(trichloromethyl) pyridine] is strongly influenced by soil organic matter (Hendrickson and Keeney, 1979; Keeney, 1980). However, little is known of the interaction between compounds such as $\mathrm{C}_{2} \mathrm{H}_{2}$ or DCD and organic matter. Acetylene, which blocks $\mathrm{N}_{2} \mathrm{O}$ reduction to $\mathrm{N}_{2}$ by denitrifiers, also is an effective inhibitor of nitrification (Bremner and Blackmer, 1979; Walter et al., 1979). Dicyandiamide, which has long been known as a nitrification inhibitor (Amberger, 1981; Reddy, 1964) is marketed by SKW Trostberg AG, Trostberg, West Germany under the trade name Didin (Hauck and Behnke, 1981).

The objective of this study was to compare the effectiveness of nityrapyrin, $\mathrm{C}_{2} \mathrm{H}_{2}$, and DCD, nitrification inhibitors that have widely differing chemical and physical properties, in a mineral and an organic soil.

\section{Materials and methods}

The soils used (Table 1) were surface ( 0 to $15 \mathrm{~cm})$ samples of Plano silt loam (Typic Arguidoll) and an organic soil (Histosol, Saprists). The samples were air dried and crushed to pass a 2-mm sieve before use. For the analyses reported in Table 1, pH in water was measured by a glass electrode, Organic $\mathrm{C}$ was determined on 100 mesh ground samples (Harris and Adams, 1979) and exchangeable $\mathrm{NH}_{4}$ and $\left(\mathrm{NO}_{2}+\mathrm{NO}_{3}\right)-\mathrm{N}$ were determined on $2 \mathrm{M} \mathrm{KCl}$

Table 1 . Analyses of soils

\begin{tabular}{lcccr} 
& & & \multicolumn{2}{c}{$\begin{array}{l}\text { Mineral N } \\
(\mu \mathrm{g} / \mathrm{g})\end{array}$} \\
\cline { 3 - 5 } Soil & $\mathrm{pH}^{\mathrm{a}}$ & Organic $\mathrm{C}$ & $\mathrm{NH}_{4}$ & $\mathrm{NO}_{3}$ \\
\hline Plano silt loam & 7.0 & 1.4 & 7 & 11 \\
Histosol & 6.8 & 40.0 & 13 & 253 \\
\hline
\end{tabular}

a Soil $\mathrm{pH}$ was measured using soil to water ratio of $1: 2$ for the Plano silt loam and 1:4 for the organic soil.

b For the experiments evaluating nitrapyrin and DCD. 
Table 2. Effects of nitrapyrin and DCD on nitrification of soil $\mathrm{N}$ in a mineral and an organic soil. Values express mineral $\mathrm{N}$ content $(\mu \mathrm{g} / \mathrm{g})$ at 14 days

\begin{tabular}{|c|c|c|c|c|c|c|}
\hline \multirow[t]{2}{*}{ Treatment } & \multicolumn{3}{|c|}{ Plano silt loam } & \multicolumn{3}{|c|}{ Histosol } \\
\hline & $\mathrm{NH}_{4}$ & $\mathrm{NO}_{3}$ & Total & $\mathrm{NH}_{4}$ & $\mathrm{NO}_{3}$ & Total \\
\hline No amendment ${ }^{\mathrm{a}}$ & 4 & 52 & 56 & 10 & 433 & 443 \\
\hline Nitrapyrin $(8 \mu \mathrm{g} / \mathrm{g})$ & 39 & 14 & 53 & 8 & 426 & 434 \\
\hline No amendment ${ }^{\mathrm{b}}$ & 4 & 37 & 41 & 6 & 461 & 467 \\
\hline $\mathrm{DCD}(20 \mu \mathrm{g} / \mathrm{g})$ & 23 & 24 & 47 & $-^{\mathrm{c}}$ & - & - \\
\hline Nitrapyrin $(20 \mu \mathrm{g} / \mathrm{g})$ & - & - & - & 7 & 466 & 473 \\
\hline $\mathrm{DCD}(50 \mu \mathrm{g} / \mathrm{g})$ & - & - & - & 8 & 478 & 486 \\
\hline $\operatorname{DCD}(100 \mu \mathrm{g} / \mathrm{g})$ & - & - & - & 16 & 466 & 482 \\
\hline
\end{tabular}

a,b Experiments done at two separate times.

$c$ Not done.

extracts by steam distillation (Bremner and Keeney, 1965).

\section{Evaluation of nitrapyrin and $D C D$}

Soil samples $(5 \mathrm{~g})$ were placed in $125 \mathrm{ml}$ Erlenmeyer flasks and treated with water or with $\left(\mathrm{NH}_{4}\right)_{2} \mathrm{SO}_{4}\left(200 \mu \mathrm{g} / \mathrm{g} \mathrm{NH}_{4}-\mathrm{N}\right)$; and nitrapyrin $(0,8$ or $20 \mu \mathrm{g} / \mathrm{g})$, or DCD $(0,20$ or $100 \mu \mathrm{g} / \mathrm{g})$ were added in aqueous solutions. The water content of the soil samples was brought to $-33 \mathrm{kPa}$. The flasks were covered with aluminium foil caps having a $1-\mathrm{mm}$ central hole (for aeration) and placed in a constant temperature cabinet at $30^{\circ} \mathrm{C}$ in a humidified atmosphere. Each treatment was in duplicate. After 14 days, inorganic $\mathrm{N}$ in the samples was analysed as described earlier.
Evalaution of $\mathrm{C}_{2} \mathrm{H}_{2}$

Soil samples $(10 \mathrm{~g})$ were incubated in $125-\mathrm{ml}$ Erlenmeyer flasks. Water was added to the samples after amendment to bring the soil moisture content to $-33 \mathrm{kPa}$ with $\mathrm{NH}_{4}-\mathrm{N}(0$ or $100 \mu \mathrm{g} / \mathrm{g})$ as $\left(\mathrm{NH}_{4}\right)_{2} \mathrm{SO}_{4}$. The flasks were stoppered with rubber septa. In the plus $\mathrm{C}_{2} \mathrm{H}_{2}$ treatments, 0.1 or $1 \%$ volume of air in the flasks was replaced by pure $(99.9 \%) \mathrm{C}_{2} \mathrm{H}_{2}$ by a syringe. The samples were incubated at $25^{\circ} \mathrm{C}$ for 1 week. Atmospheres in the flasks were replaced at 4 days by humidified air and appropriate amounts of $\mathrm{C}_{2} \mathrm{H}_{2}$ added. Preliminary experiments showed that the rubber septa used were leakproof, and the concentrations of $\mathrm{C}_{2} \mathrm{H}_{2}$ inside the flasks stoppered with the septum was maintained during the duration of the experiment. After 1 week, the soil samples were analysed for inorganic $\mathrm{N}$ as described earlier.

Inhibition of nitrification was calculated by the difference between the $\mathrm{NO}_{3}-\mathrm{N}$ produced during incubation in the control and inhibitor-treated soils (Bundy and Bremner, 1973).

\section{Results and discussion}

Results on the effects of nitrapyrin, DCD and $\mathrm{C}_{2} \mathrm{H}_{2}$ on nitrification of soil or added ammonium are presented in Tables 2, 3 and 4. These results indicate that total mineral $\mathrm{N}$ balance in the Plano soil and in the Histosol with and without inhibitor treatments were close, suggesting little loss of mineral $\mathrm{N}$ due to denitrification during the study.

Table 3. Effects of nitrapyrin and DCD on nitrification in soils treated with ammonium sulfate (AS, $200 \mu \mathrm{g} / \mathrm{g}$ soil). Values express mineral $\mathrm{N}$ content $(\mu \mathrm{g} / \mathrm{g})$ at 14 days

\begin{tabular}{|c|c|c|c|c|c|c|}
\hline \multirow[t]{2}{*}{ Treatment } & \multicolumn{3}{|c|}{ Plano silt loam } & \multicolumn{3}{|c|}{ Histosol } \\
\hline & $\mathrm{NH}_{4}$ & $\mathrm{NO}_{3}$ & Total & $\mathrm{NH}_{4}$ & $\mathrm{NO}_{3}$ & Total \\
\hline $\mathrm{AS}^{\mathrm{a}}$ & 28 & 207 & 235 & 8 & 623 & 631 \\
\hline AS + Nitrapyrin $(8 \mu \mathrm{g} / \mathrm{g})$ & 234 & 15 & 249 & 7 & 624 & 631 \\
\hline $\mathrm{AS}^{\mathrm{b}}$ & 43 & 180 & 223 & 8 & 675 & 683 \\
\hline AS + Nitrapyrin $(8 \mu \mathrm{g} / \mathrm{g})$ & 234 & 4 & 238 & $-^{c}$ & - & - \\
\hline $\mathrm{AS}+\mathrm{DCD}(20 \mu \mathrm{g} / \mathrm{g})$ & 208 & 23 & 231 & - & - & - \\
\hline AS + Nitrapyrin $(20 \mu \mathrm{g} / \mathrm{g})$ & - & - & - & 29 & 639 & 668 \\
\hline $\mathrm{AS}+\mathrm{DCD}(10 \mu \mathrm{g} / \mathrm{g})$ & - & - & - & 157 & 508 & 665 \\
\hline
\end{tabular}

a.b Experiments conducted at two separate times.

c Not done. 
Table 4. Effects of $\mathrm{C}_{2} \mathrm{H}_{2}$ on nitrification of soil and added ammonium in soils. Values express mineral $\mathrm{N}$ content $(\mu \mathrm{g} / \mathrm{g})$ at 7 days

\begin{tabular}{|c|c|c|c|c|}
\hline \multirow{2}{*}{\multicolumn{2}{|c|}{$\begin{array}{l}\mathrm{NH}_{4}-\mathrm{N} \text { added } \\
(\mu \mathrm{g} / \mathrm{g})\end{array}$}} & \multicolumn{3}{|c|}{$\mathrm{C}_{2} \mathrm{H}_{2}(\%, v / v)$} \\
\hline & & 0 & 0.1 & 1.0 \\
\hline \multicolumn{5}{|c|}{ Plano silt loam ${ }^{\mathrm{a}}$} \\
\hline \multirow[t]{3}{*}{0} & $\mathrm{NH}_{4}-\mathrm{N}$ & 6 & 39 & 37 \\
\hline & $\mathrm{NO}_{3}$ & 41 & 13 & 12 \\
\hline & Total & 47 & 52 & 49 \\
\hline \multirow[t]{3}{*}{100} & $\mathrm{NH}_{4}$ & 79 & 127 & 127 \\
\hline & $\mathrm{NO}_{3}$ & 60 & 13 & 12 \\
\hline & Total & 139 & 140 & 139 \\
\hline \multicolumn{5}{|c|}{ Histosol $^{\mathrm{b}}$} \\
\hline \multirow[t]{3}{*}{0} & $\mathrm{NH}_{4}$ & 13 & 189 & 196 \\
\hline & $\mathrm{NO}_{3}$ & 444 & 262 & 264 \\
\hline & Total & 457 & 451 & 460 \\
\hline \multirow[t]{3}{*}{100} & $\mathrm{NH}_{4}$ & 71 & 295 & 295 \\
\hline & $\mathrm{NO}_{3}$ & 494 & 266 & 263 \\
\hline & Total & 565 & 561 & 558 \\
\hline
\end{tabular}

a The soil contained $\mathrm{NH}_{4}, 9 \mu \mathrm{g} / \mathrm{g} ; \mathrm{NO}_{3}, 12 \mu \mathrm{g} / \mathrm{g}$ at the start of the experiment.

b The soil contained $\mathrm{NH}_{4} 16 \mu \mathrm{g} / \mathrm{g} ; \mathrm{NO}_{3}, 268 \mu \mathrm{g} / \mathrm{g}$ at the start of the experiment.

With the mineral soil, nitrapyrin was considerably more effective in inhibiting nitrification of indogenous ammonium in the soil than DCD but both were equally effective with added $\mathrm{NH}_{4}$ (Table 2, 3 and 5). However, neither compound was effective with the Histosol. In contrast, $\mathrm{C}_{2} \mathrm{H}_{2}$ was an

Table 5. Nitrification inhibition $(\%)^{e}$ by nitrapyrin, DCD or $\mathrm{C}_{2} \mathrm{H}_{2}$

\begin{tabular}{lcccccc}
\hline Inhibitor & & \multicolumn{2}{c}{ Plano silt loam } & \multicolumn{2}{c}{ Histosol } \\
\cline { 1 - 3 } \cline { 5 - 7 } Compound & Rate & & $0^{\mathrm{a}}$ & $+\mathrm{NH}_{4}^{\mathrm{b}}$ & $0^{\mathrm{a}}$ & $+\mathrm{NH}_{4}$ \\
\hline Nitrapyrin $^{\mathrm{c}}$ & $8 \mu \mathrm{g} / \mathrm{g}$ & 93 & 98 & 4 & 0 \\
& $20 \mu \mathrm{g} / \mathrm{g}$ & - & - & 0 & 8 \\
$\mathrm{DCD}^{\mathrm{c}}$ & $20 \mu \mathrm{g} / \mathrm{g}$ & 50 & 93 & - & - \\
& $100 \mu \mathrm{g} / \mathrm{g}$ & - & - & 0 & 39 \\
$\mathrm{C}_{2} \mathrm{H}_{2}^{\mathrm{d}}$ & $0.1 \% \mathrm{v} / \mathrm{v}$ & 97 & 98 & 100 & 100 \\
& $0.1 \% \mathrm{v} / \mathrm{v}$ & 100 & 100 & 100 & 100
\end{tabular}

a Non-amended soil.

b Soil amended with $200 \mu \mathrm{g} \mathrm{NH}_{4}-\mathrm{N} / \mathrm{g}$ soil for evaluation of nitrapyrin and DCD, and with $100 \mu \mathrm{g} \mathrm{NH}_{4}-\mathrm{N} / \mathrm{g}$ soil for evaluating $\mathrm{C}_{2} \mathrm{H}_{2}$.

- 14 days at $30^{\circ} \mathrm{C}$

d 7 days at $25^{\circ} \mathrm{C}$.

e $\%$ inhibition of nitrification $=$

$\left(\mathrm{NO}_{3}-\mathrm{N}\right.$ produced in control soil $)-\left(\mathrm{NO}_{3}-\mathrm{N}\right.$ produced in inhibitor-treated soil) $\times 100$ extremely effective inhibitor of nitrification in both soils (Table 4 and 5).

The organic soil we used had an extremely rapid nitrification rate. This, coupled with high temperature $\left(25\right.$ to $\left.30^{\circ} \mathrm{C}\right)$ and optimum water and aeration status of the incubation procedure used, provided an extreme test of nitrification inhibitor efficacy.

It would appear that the sorption of nitrapyrin by organic matter was the probable reason for the ineffectiveness of this compound with the organic soil (Hendrickson and Keeney, 1979). We are not certain why DCD was ineffective in the Histosol. DCD could be rapidly degraded in this soil although Vilsmeir (1981) indicates that at $25^{\circ} \mathrm{C}$ about $50 \%$ of the added DCD remained after 2 weeks in a sandy loam soil. It is not strongly sorbed by soil constituents (Ashworth and Rodgers, 1981; Bock et al., 1981) although the rate of DCD leaching was found to be inversely related to organic matter content (range 0.7 to $5.3 \%$ organic matter) in six soils studied by Bock et al. (1981).

The effectiveness of $\mathrm{C}_{2} \mathrm{H}_{2}$ in the organic soil is related to the fact that this compound, added as a gas, can completely permeate the soil matrix. Further, the experimental design was such that it was replaced at day four and thus degradation in the soil was not a major factor.

These results show that the inhibitors are differentially effective in mineral vs. organic soil, which could be due to differential retention and mobility in the two soils. An ideal compound might be a 'slow release' inhibitor with a high vapour pressure and low organic matter retention characteristics.

\section{Acknowledgement}

Research supported by the College of Agricultural and Life Sciences and by the National Science Foundation (DEB 7817404).

\section{References}

Amberger A 1981 Dicyandiamide as a nitrification inhibitor. In Proc. Technical Workshop on Dicyandiamide. Ed. R D Hauck and H Behnke, pp. 3-17. SKW Trostberg, West Germany. 
Ashworth J and Rodgers G A 1981 The compatibility of the nitrification inhibitor dicyandiamide with injected ammonia. Can. J. Soil Sci. 61, 461-463.

Bock B R, Lawrence J E and Williams H M 1981 Relative mobility of dicyandiamide, ammonium and urea by mass flow in soils. In Proc. Technical workshop on Dicyandiamide. Ed. R D Hauck and H Behnke, pp 25-37. SKW Trostberg, West Germany.

Bremner J M and Blackmer A M 1979 Effects of acetylene and soil water content on emission of nitrous oxide from soils. Nature 280, 380-381.

Bremner J M and Keeney D R 1965 Steam distillation methods for determination of ammonium, nitrate and nitrite. Anal. Chim. Acta 32, 485-495.

Bundy $L \mathrm{G}$ and Bremner J M 1973 Inhibition of nitrification in soils. Soil Sci. Soc. Am. Proc. 37, 396-398.

Harris R F and Adams S S 1979 Determination of carbonbound electron composition of microbial cells and metabolites by dichromate oxidation. Appl. Environ. Microbiol. $37,237-243$.

Hauck R D and Behnke H (Eds.) 1981 Proc. Technical work- shop on Dicyandiamide. SKW Trostberg AG, West Germany, $148 \mathrm{p}$.

Hendrickson L L and Keeney D R 1979 A bioassay to determine the effect of organic matter and $\mathrm{pH}$ on the effectiveness of nitrapyrin ( $\mathrm{N}$-serve) as a nitrification inhibitor. Soil Biol. Biochem. 11, 51-55.

Keeney D R 1980 Factors affecting the persistence and bioactivity of nitrification inhibitors. In Nitrification inhibitors potentials and limitations. Eds. J J Meisinger et al., Special Publication No. 38, pp. 33-46. Amer. Soc. of Agronomy, Madison, Wisconsin.

Reddy, G R 1964 Effects of mixing varying quantities of dicyandiamide with ammonium fertilizers on nitrification of ammonia in soils. Can. J. Soil Sci. 44, 254-259.

Vilsmeir K 1981 Action and degradation of dicyandiamide in soils. In Proc. Technical Workshop on Dicyandiamide. Eds. R D Hauck and H Behnke, pp. 18-24., SKW Trostberg, West Germany.

Walter H M, Keeney D R and Fillery I R 1979 Inhibition of nitrification by acetylene. Soil Sci. Soc. Am. J. 43, 195-196. 